\title{
Professional Identity and Turnover Intention among Staff Nurses in Different
}

\author{
Sectorial Hospitals \\ Rabab M. Hassan * and Wafaa A. Elhosany** \\ Assist. professor, Nursing Administration, Faculty of nursing, Ain Shams University* and Suez Canal \\ University**
}

\begin{abstract}
Background: Professional identity is a concept that attracted a great deal of attention at work place for better understanding of employees' attitudes and work related outcomes. It helps staff nurses to persist in their job and profession for long period. Both professional identity and turnover intention are highly related to staff nurses work life. Aim: This research aims to assess nature of professional identity and examine its relationship with turnover intention among nurses in different sectorial hospitals.
\end{abstract}

Research design: A comparative, correlational design was used.

Study Subjects: 457staff nurses from Suez Canal university hospital and Shubra general hospital were participated in the study. Two tools were used namely; professional identity questionnaire and turnover intention questionnaire. Results: Professional identity was higher among staff nurses working in Suez Canal university hospital than staff nurses working in Shubra general hospital. Turnover intention was higher among staff nurses working in Shubra general hospital than staff nurses working in Suez Canal university hospital.

Conclusion: There were statistically significant positive correlations between professional identity and staff nurses' age and years of experience. There were statistically significant negative correlations between turnover intention and staff nurses' age and years of experience. There was statistically negative correlation between professional identity and turn over intention among staff nurses in both study settings.

Recommendations: develop staff nurses professionally through boosting up their assertive behavior. Nurse Managers should develop strategies to knob turnover intention.

Keywords: Professional identity, Staff nurses, Turnover intention.

\section{Introduction}

Professional identity refers to the attitudes, beliefs, knowledge and skills shared within a professional group and related to the professional roles undertaken by them (Fagermoen, 2010). It is a component of person' total identity and augmented by his/ her position within the community, interactions with others and the interpretations of experience (Adams, 2011). Also, it is the nurse' professional self-perception or self-concept regarding their nursing abilities in general (Cowinet al., 2008).

Professional identity develops as a result of the internalization of professional knowledge, skills, attitudes, values and standards of ethics, and the integration of these characteristics into one's personal identity and behaviors within nursing education and practice (Cowin et al. 2013). A nurse with a strong professional identity works in harmony with the professional values and ethical codes, and is adequately aware about his/her role which fulfills completely (Hwang et al. 2009, Celik\&Hisar 2012). It is possible to assume that the growth of professional identity might raise nurses' knowledge and the potential to apply it in the practice, which in return, may enhance their job satisfaction. In addition, it can be assumed that sufficient development of professional identity can enhance employee autonomy, raise professional self-confidence and trust and ability to communicate effectively, all of which are likely to increase job fulfillment and adjustment (Deppoliti, 2008, Hwang et al. 2009, Sharbaugh 2009).

Professional identity comprises the full utilization of nurses' knowledge, skills, and abilities with clear definition of the margins of miscellaneous professions. It's clear understanding, either at individual or discipline sphere that professional identity could empower nurses to reflect an additional responsible and equitable role, change the traditional approach of how nurses are perceived themselves and are perceived by others, develop further pertinent thoughts about professional identity (Friberg and Creasia, 2016; Giddens, 2017). Positive workplace identity is crucial to get higher functioning level and benefits for both health care customers and providers. Being professional contributes to establishment of self-belief and effective communication, it can immunize nurse against bullying, humility and discrimination in the workplace, so professional identity can assist in declining turnover (Harrison and Williams, 2016; Gault et al., 2017).

Nurses are the largest health professionals group within the global health care system, with a total of 19.3 million nursing and midwifery personnel around the world (WorldHealth Organization (WHO), 2011). 
The current and growing shortage of registered nurses in health care systems is a global concern (Buckhan\&Aikan,2008, Juraschek, Zhang, Ranganathan\&lin,2012;Cole, 2014). In fact, the European Commission has estimated that there will be a shortage of 590,000 nurses by the year 2020(Sermeus \&Bruyneel,2010).Turnover intention appears to be a trend and has been found to forecast the actual decision to leave the profession( Takase,2010). Turnover involves employee departure of an organization and the need to be replaced. In Egypt, El Dahshan and Keshk (2014) reported that 34.2\% of male nurses and $14 \%$ of female nurses had the intention to leave their workplace in El Menoufia governorate. Also, Mosallam et al. (2015) found that $65 \%$ of ICU nurses had high turnover intention in Alexandria, Egypt.

Nurses' turnover rate is among the highest rates of professional groups. Turnover can lead to many undesirable direct and indirect consequences to health care settings and patient's quality of care and safety. Direct cost of turnover is representing in advertising, recruiting and training new staff, while the indirect cost includes low productivity and morale of the staff and customer satisfaction. In addition, nurses' turnover results in poor health care coordination, management and hospital economic matters. The residual staff members are also affected through heavier workloads, and longer shifts which consequently associated with low job satisfaction and burnout among nurses (Mosadeghrad, 2013, McGiltona etal., 2014; Roussel et al., 2016).

Turnover intention appears to be a multistage process consisting of psychological, cognitive, and behavioral components. The peak of nurses' turnover occurs within the first year of recruitment (Flinkman, 2013). The main reported factors that foster nurses to leave their job include personal and family obligations, work environment, quality of work life. Also, organizational culture, work related stress, excessive job demands, clinical competence, leader effectiveness and promotion system. Key factors of nurses' retention include nurses identity, communication, involvement, and preparedness to conflict management (Cortese,2012, Dasgupta and Agarwal, 2014; Moreland et al., 2015).

\section{Significance of the study:}

Staff nurses' professional identity is influenced by many factors. Staff nurses are expected to seek professional development and retaining in their job and profession. In the time hospitals are suffering from shortage in nursing personnel and the consequence of this shortage on patient and organization outcomes, the search about professional identity and turnover intentions among nurses is highly needed to detect is it a phenomenon all over health care sectors or particular to certain sector?. Also, there is few Egyptian researches which studying professional identity and its' influence to intention to leave the job, hospital and may be the profession. So, the present study was conducted to assess professional identity and turnover intention among staff nurses in different sectorial hospitals. The following research questions will guide the research study:

-Is there a difference between studied staff nurses in different sectorial hospitals regarding their professional identity?

-Is turn over intention distinction between staff nurses working in different sectorial hospitals?

-What is the nature of the relationship between professional identity and turnover intention among studied staff nurses in different sectors?

\section{Research Design:}

\section{Subjects and Methods}

A comparative, correlational design was used to achieve the aim of this study.

\section{Setting:}

The study was carried out in two different sectorial hospitals. The first hospital is Suez Canal University hospital in Ismailia Governorate which affiliated to University hospitals sector. While the second hospital is Shubra General hospital in Cairo Governorate which affiliated to ministry of health hospitals.

\section{Subjects:}

457 staff nurses were included in the study. They divided as follow: 235 staff nurses from Suez Canal university hospital and 222 staff nurses from Shubra General Hospital. Subjects of the study were working in different units in the previous mentioned hospitals. They were selected randomly. The inclusion criteria were permanent staff with full time work, had at least one year experience in the unit and accept to participate in the study.

Tools of Data Collection:

Two questionnaire sheets were used to collect study data.

a- Professional identity Questionnaire:

It aimed to assess the level of professional identity among staff nurses. It developed by Kabeel, (2004) and modified by the researchers. It composed of 56 items under three main dimensions: Self-image (27 items), assertiveness (25 items) and self-responsibility (4 items). 


\section{Scoring system:}

Staff nurse response was scored on 5 point Likert scale. It ranged from 1 "strongly disagree" to 5 "strongly agree". The scoring reversed for negative items. The scores of each dimension summed up and converted into percent score. Professional identity considered high if the percent score was equal or more than $60 \%$ and low if the score was less than $60 \%$.

\section{b- Turnover intention Questionnaire:}

This tool was developed by Jourdain and Chenevert, (2010) and modified by the researchers. It aimed to measure employee intention to leave the present job. It contains 12 items.

\section{Scoring system:}

Response for each item was scored on 5 point Likert scale $(1=$ Never, $2=$ rarely, $3=$ Sometimes, $4=$ Often, and 5=Always).The scoring system was reversed in the negative items. The scores converted into percent scores. Turnover intention considered positive if the percent score was $60 \%$ or more and it considered negative which meaning intention to stay if the percent score was less than $60 \%$.

\section{Pilot study:}

Pilot study was conducted on 46 staff nurses who represent $10 \%$ of the total study subjects. Pilot study examined tools feasibility, simplicity, and clarity of the tools. It also used to estimate the time needed to fill in the sheets which ranged between 30-40 minutes. Validity and reliability of the study tools were tested. Tools were validated by jury group consisted of 7 experts in nursing administration and psychiatric nursing. To ascertain relevance, clarity, completeness of the tools based on their remarks and comments, necessary modifications were done. Cronbach's alpha coefficient was used to assess the reliability of the study tools through internal consistency. It turned to be 0.93 for professional identity questionnaire and 0.91 for turnover intention.

\section{Field work:}

The researchers collected the data in two days per week in different shifts. Through meeting staffnurses either individually or in groups at their work units after explaining the aim of the study and its' benefits for them and their hospitals, the researchers clarified the methods of filling the questionnaire sheets to the participants. The researchers were available for clarifying any ambiguity and check each sheet after filling for its completion. Data were collected from September 2015 to February 2016.

\section{Administrative and ethical considerations:}

An official permission to conduct the study was secured. Informed consent was obtained from each staff nurse after explaining the purpose of the research and its' implications and before data collection. The researchers assured that participation in the study was voluntary and participants had the right to withdraw from the study at any time. Confidentiality of the collected data were assured and the questionnaire sheets were anonymous.

\section{Statistical analysis:}

Data were coded, entered, analyzed and tabulated using SPSS version 16. Descriptive statistics presented in the form of frequency, percentage. Qualitative categorical variables were compared using chisquare test. Pearson correlation analysis was used for assessing the inter-relationships among variables. Statistical significance was considered at $\mathrm{p}$-value $<0.05$.

\section{Results}

Table (1): Demographic characteristics of staff nurses in two studied settings.

\begin{tabular}{|c|c|c|c|c|}
\hline \multirow[t]{2}{*}{ Demographic characteristics } & \multicolumn{2}{|c|}{$\begin{array}{l}\text { Suez Canal University hospital } \\
\qquad(n=235)\end{array}$} & \multicolumn{2}{|c|}{$\begin{array}{l}\text { Shubra General hospital } \\
\qquad(\mathrm{n}=222)\end{array}$} \\
\hline & & $\%$ & & $\%$ \\
\hline $\begin{array}{l}\text { Age(Years): } \\
<30 \\
30-40 \\
>40\end{array}$ & $\begin{array}{c}166 \\
61 \\
8\end{array}$ & $\begin{array}{l}70.6 \\
26 \\
3.4\end{array}$ & $\begin{array}{c}69 \\
114 \\
39\end{array}$ & $\begin{array}{l}31.1 \\
51.4 \\
17.5\end{array}$ \\
\hline Mean \pm SD & \multicolumn{2}{|c|}{$28.27 \pm 5.38$} & \multicolumn{2}{|c|}{$33.65 \pm 6.86$} \\
\hline $\begin{array}{l}\text { Gender: } \\
\text { Male } \\
\text { Female }\end{array}$ & $\begin{array}{c}31 \\
204\end{array}$ & $\begin{array}{l}13.2 \\
86.8\end{array}$ & $\begin{array}{c}88 \\
134\end{array}$ & $\begin{array}{l}39.6 \\
60.4\end{array}$ \\
\hline $\begin{array}{l}\text { Qualifications in Nursing: } \\
\text { Diploma }\end{array}$ & & & & \\
\hline
\end{tabular}




\begin{tabular}{|c|c|c|c|c|}
\hline $\begin{array}{l}\text { High average diploma } \\
\text { Bachelor degree }\end{array}$ & $\begin{array}{c}128 \\
87 \\
20 \\
\end{array}$ & $\begin{array}{c}54.5 \\
37 \\
8.5 \\
\end{array}$ & $\begin{array}{c}136 \\
62 \\
24 \\
\end{array}$ & $\begin{array}{l}61.2 \\
27.9 \\
10.9 \\
\end{array}$ \\
\hline $\begin{array}{l}\text { Type of work unit: } \\
\text { Critical } \\
\text { Non critical }\end{array}$ & $\begin{array}{c}85 \\
105\end{array}$ & $\begin{array}{l}36.2 \\
63.8\end{array}$ & $\begin{array}{c}141 \\
76\end{array}$ & $\begin{array}{l}63.5 \\
36.5\end{array}$ \\
\hline $\begin{array}{l}\text { Years of experience: } \\
<15 \\
15-25 \\
>25\end{array}$ & $\begin{array}{c}134 \\
82 \\
19\end{array}$ & $\begin{array}{c}57 \\
34.9 \\
8.1\end{array}$ & $\begin{array}{c}58 \\
127 \\
37\end{array}$ & $\begin{array}{l}26.1 \\
57.2 \\
16.7\end{array}$ \\
\hline Mean \pm SD & & & & \\
\hline
\end{tabular}

Table (1) demonstrates that more than two thirds (70.6\%) of staff nurses in Suez Canal university hospital had age less than 30 years, while slight above half of staff nurses at Shubra General hospital had age ranged between 30 to 40 years old. Majority of studied staff nurses in both study settings were female, more than half of staff nurses $(54.5 \%)$ in Suez Canal university hospital and less than two thirds

(61.2\%) of staff nurses in Shubra general hospital had nursing school diploma. Regarding type of work unit, more than one third of staff nurses at Suez Canal University hospital and less than two thirds of staff nurses at Shubra General hospital working in critical care units. Regarding Years of experience, more than half (57\%) of staff nurses at the university hospital had less than 15 years ,meanwhile more than half of staff nurses (57.2\%) at the general hospital had years of experience ranged between 15 to 25 years.

Table (2): Comparison between staff nurses score regarding professional identity dimensions in two study settings.

\begin{tabular}{|c|c|c|c|c|c|}
\hline $\begin{array}{l}\text { Professional } \\
\text { Identity } \\
\text { dimensions }\end{array}$ & $\begin{array}{l}\text { Staff nurses at Suez Canal } \\
\text { University hospital } \\
(n=235) \\
\text { No. } \quad \%\end{array}$ & $\begin{array}{l}\text { Staf } \\
\text { Gen } \\
(\mathbf{n}=2 \\
\text { No. }\end{array}$ & $\begin{array}{l}\text { ses at Shubra } \\
\text { hospital } \\
\%\end{array}$ & $\begin{array}{l}\text { Chi- } \\
\text { square }\end{array}$ & P- value \\
\hline Professional image & 71.4 & 126 & 56.7 & 10.80 & $0.001^{*}$ \\
\hline Assertiveness & 56.6 & 96 & 43.2 & 8.14 & $0.004 *$ \\
\hline Self-responsibility & 41.7 & 83 & 37.4 & 0.889 & 0.346 \\
\hline
\end{tabular}

(*) Statistically significant at $p<0.05$

Table (2) Clarifies that staff nurses in both Suez Canal university hospital and Shubra General hospital had the highest percent score regarding professional image $(71.4 \%, 56.7 \%)$ respectively. Conversely, selfresponsibility had the lowest score $(41.7 \%, 37.4 \%)$ respectively.. Also there was h statistically significant difference between both study subjects regarding professional image and assertiveness.

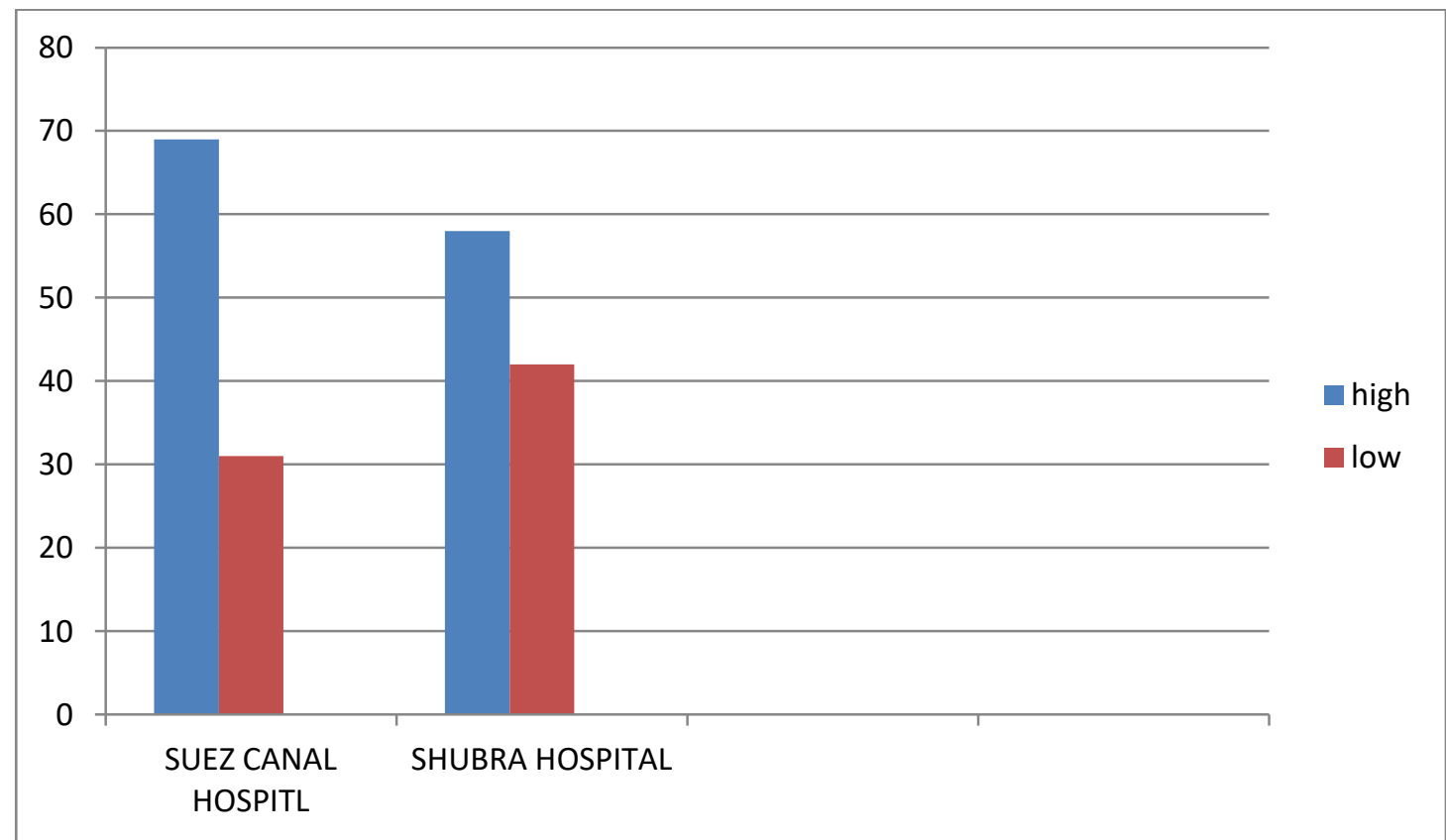

Figure (1): Total professional identity level among staff nurses in two studied hospitals.

Figure (1) presents that total professional identity was higher among staff nurses working at Suez Canal university hospital than staff nurses working in Shubra university hospital. 
Table (3): Turn over intention among nurses in two studied hospitals.

\begin{tabular}{|c|c|c|c|c|}
\hline $\begin{array}{l}\text { Turnover } \\
\text { intention }\end{array}$ & $\begin{array}{l}\text { Staff nurses in Suez Canal } \\
\text { University hospital }(n=235) \\
\text { No } \quad \%\end{array}$ & $\begin{array}{l}\text { Staff nurses in Shubra } \\
\text { General hospital }(n=222) \\
\text { No } \quad \%\end{array}$ & Chi -square & P-value \\
\hline Positive & 28.1 & 61.7 & \multirow[t]{2}{*}{52.29} & \multirow[t]{2}{*}{$0.000 *$} \\
\hline Negative & 71.9 & 38.3 & & \\
\hline
\end{tabular}

(*) Statistically significant at $\mathrm{p}<0.05$

Table (3) Illustrates that turn over intention was more positive among staff nurses working in Shubra general hospital than those who working in Suez Canal university hospital. There was statistically significant difference between staff nurses in both study hospitals regarding turnover intention.

Table (4): Correlations between total professional identity and staff nurses demographic characteristics in both study settings.

\begin{tabular}{|c|c|c|c|c|}
\hline \multirow{3}{*}{ Staff nurses demographic Characteristics } & \multicolumn{4}{|c|}{ Total professional identity score } \\
\hline & \multicolumn{2}{|c|}{$\begin{array}{l}\text { Suez Canal university } \\
\text { hospital }\end{array}$} & \multicolumn{2}{|c|}{$\begin{array}{l}\text { Shubra } \\
\text { General } \\
\text { Hospital }\end{array}$} \\
\hline & $\mathbf{r}$ & $\mathbf{p}$ & $\mathbf{r}$ & $\mathbf{P}$ \\
\hline Age & 0.101 & 0.483 & 0.043 & 0.155 \\
\hline Years of experience & 0.209 & $0.024 *$ & 0.762 & $0.044 *$ \\
\hline
\end{tabular}

(*) Statistically significant at $\mathrm{p}<0.05$

Table (4) illustrates that there were statistically significant positive correlations between total professional identity and staff nurses' age and years of experience.

Table (5): Correlations between turnover intension and demographic characteristics of studied nurses in two hospitals

\begin{tabular}{|c|c|c|c|c|}
\hline \multirow{3}{*}{ Staff Nurses demographic Characteristics } & \multicolumn{4}{|c|}{ Turnover intention score } \\
\hline & \multicolumn{2}{|c|}{$\begin{array}{c}\text { Suez Canal university } \\
\text { hospital }\end{array}$} & \multicolumn{2}{|c|}{$\begin{array}{c}\text { Shubra } \\
\text { General } \\
\text { hospital }\end{array}$} \\
\hline & $\mathbf{r}$ & $\mathbf{p}$ & $\mathbf{r}$ & $\mathbf{p}$ \\
\hline Age & -0.095 & $0.512 *$ & 0.037 & $-0.799 *$ \\
\hline Years of experience & -0.283 & $0.035^{*}$ & 0.304 & $-0.061 *$ \\
\hline
\end{tabular}

(*) Statistically significant at $\mathrm{p}<0.05$

Table (5) demonstrates that there were statistically significant negative correlations between turnover intention and age, and years of experience among staff nurses in both study settings.

Table (6): Correlations between total professional identity and turnover intention among staff nurses at two study settings.

\begin{tabular}{|c|c|c|c|}
\hline \multicolumn{4}{|c|}{ Turn over intention } \\
\hline & \multicolumn{2}{|c|}{ Suez Canal university } & Shubra hospital \\
\hline & $\mathrm{R}$ & p-value & p-value \\
\hline Professional identity & -0.726 & $0.05 *$ & -0.834 \\
\hline
\end{tabular}

(*) correlation at $\mathrm{p}<0.05$

Table (6) reveals that there was highly statistically significant negative correlation between total professional identity and turnover intention among staff nurses in both studied hospitals.

\section{Discussion}

Health care system facing serious issues due to work over loads, decreasing of required resources and the global shortage of nursing staff which place a heavy burden on the health care providers. Nurses are considered as the front line staff who deal with high level of stress, information technology and deaths every day in most health care organizations (Herholdt, 2015). All these difficulties influences work performance and nurse work related attitude and behavior such as organizational commitment, satisfaction, voluntary absenteeism and staff desire to remain in the organization (Seid,2015).

Finding of the present study revealed that professional image was higher among staff nurses working in Suez Canal university hospital than those working in Shubra General Hospital. This result may be attributed to
DOI: 10.9790/1959-0604012937
www.iosrjournals.org
33 | Page 
that the university hospital had its' own characteristics, policies, benefits and opportunities which afford selfrecognition and self-esteem to its staff, also the university hospital staff nurses had various opportunities to attend and participate in scientific conferences, workshops and staff development activities that boost their proud sense of the profession so improve their professional image. In this regard, Iacobucci et al. (2013) indicated that the higher levels of self-esteem contribute to one's subjective feelings of value as a professional that constitutes the professional identity.

The current study finding revealed that the assertiveness dimension score was higher among staff nurses working at Suez Canal University hospital than those at Shubra general hospital. This result may be attributed to that staff nurses daily face stressful and critical events that need fast vital decisions, moreover staff nurses are the main responsible member in health care team about patient's condition progress from the perspectives of patients and their families, also workplace provides freedom and support for their staff. Nurses are the engine of patient care process as they coordinate the effort and kick off the cooperation of health care team members so they need to be assertive. This finding agreed with Friberg \& Creasia (2016) who found that the professional nurse examples held themselves to high standards and be highly assertive and saw this as a reflection of their standing as a professional qualified nurse, not just their personal reputation. Professional nurse is a vital member of an identified group or team rather than as a singular person completing a task.

The present study clarified unexpected finding that self-responsibility had the lowest score among participant staff nurses from different sectors. From the researchers point of view this finding may be attributed to low scope and concern about professional nursing role models. In this regards, a number of studies examined the development of professional identity (Severinson and Sand, 2010; McNiesh et al, 2011; Hoeve et al.,2014) highlighted the importance of role model in nursing field and their impact and they should be trusted and supported by hospital staff to learn and develop nurses' professional identity.

Staff nurses feel that they have not any responsibility or obligations toward nursing profession and they had not any role in their profession development. These feelings may be as a result of their limited participation in decision making process in their hospitals especially in related issues. Also, limited marketing and advertising about nursing syndicate activities resulted in inadequate participation of staff nurses in these activities which in turn lead to overtake sense of carless and dissatisfaction about the profession and job and low professional commitment and retaining among staff nurses .

Professional image was the highest domain among staff nurses in both study settings, this result may be due to nurses are part of their community and its view and perceptions about nursing profession and the multiple precious roles offered by nurses either in the workplace or all over the community had the positive effect on nurses. This finding was matched with Miskelly \& Duncan (2014) who emphasized the effect of social, political, and managerial aspects of providing care and their impact on professional identity and empowerment and found great influence of these aspects on nurses' empowerment and professional identity.

This study finding clarified that professional identity among staff nurses working in the university hospital was higher than those working in the general one. This result may be ascribed to benefits and prestige offered by the workplace of university hospitals. Also, most of their staff especially nurses had got high grades during their nursing education and they had multiple opportunities and advantages for in-service and off job training which improve and enhance their professional identity.

The present study found that there were statistically significant correlations between staff nurses' professional identity and staff nurses' age and years of experience in both study settings. This result may be due to retaining knowledge and experience among staff nurses who had more years of experience and had brawny emphasis and influence on other staff. Also, old, experienced staff nurses had several opportunities for professional development and promotion which promote their identity. These results granted with Benner et al . (2010) who clarified that the formation of professional values and identity occurs over time with transformation through experiential learning. Furthermore, Johnson et al. (2012) stated that professional identity is linked to self-identity which starts before nursing school and continues afterward. Also, Hoeve et al. (2014) cited strong influences between nurses' background and experiences which asserting ethics, values and professionalism.

The results of the present study revealed that less than two thirds of staff nurses who working in Shubra General hospital had positive turnover intention. This result may be due to many reasons as work overload, excessive work hours which affect their personal and family life, shortage of nurses and improper work environment. This result agreed with Rainayee (2013), Steinmetz et al. (2014) and ElSakka (2016) who indicated that the intention to withdraw from workplace could be a result of excessive job demands, excessive and long working hours without adequate benefits and multiple sources of work stress and may initiate their decision to leave their job. Hence, the final decision to leave the profession is likely to be the result of an individual reflection process with multiple causes (Al Malki et al.,2012,Momanyi\& Kaimenyi,2015 ; Thirapatsakun et al., ,2015)

On the other hand, less than three quarters of staff nurses working in Suez Canal university hospital had a negative intention to leave their job. This result may be attributed to the established benefits and 
advantages they taken from the hospital and its related sector, and the lower flow rate of patient compared to general hospital. In addition to the limited job opportunities in different health care sectors especially private sector at Ismailia Governorate.

The present study finding clarified that university hospital staff nurses had lower intention to leave compared to those in general hospital. This result congruent with ELDahshan and Keshik (2014) who indicated that high intention to stay was noticed among nurses working at university hospital. Also, Getie et al. (2015) found that more than half of staff nurses indicating turnover intention from their current health care institution.

From the current study finding it was observed that there was a statistically significant negative correlation between turnover intention among staff nurses in both settings and their age, that means intention to leave is high among younger staff, this could be related to imbalance between effort and reward, excessive job demands, young staff searching to work in organizations give high salary and had multiple opportunities for promotion and development, they also concerned with working outside the country and abroad. This study result is in accordance with Salminen (2012),Shcklock et al. (2015); Drennan et al. (2015) who found that younger nurses are most willing to leave job and nursing profession. On the other hand, Adriaenssens et al. (2015) and Omar et al. (2015) concluded that turnover intention was not significantly related to demographic characteristics.

The finding of the current study clarified that there was a statistically significant negative correlation between turnover intention and years of experience in both settings, staff nurses with more years of experience had low intention to leave their work place. This could be ascribed to staff nurses with long years of experience are more familiar with work and hospital system, demands, and had strong relations with all employees in the hospital from different departments either medical or non-medical so they had high level of commitment to their work and hospital. Also, Egyptian emotions and loyalty to their work place is the significant cause of low turn over intention among older staff This finding was in agreement with Yeun and Kim (2015); Yeun and Jeon (2015) who concluded that staff nurses with few years of experience had high intention to leave their work. Meanwhile, this result was contradicted with the finding of Mosallam et al. (2015) who concluded that there was no significant relation between turnover intention and years of experience.

Finally the present study revealed that there was a statistically significant negative correlation between professional identity and staff nurses' turnover intention in both settings. The present finding is congruent with Sabanciogullari and Dogan(2015) who concluded that intention to leave the job was greater among the nurses with low professional identity. Professional identity is a factor affecting job satisfaction. Both professional identity and job satisfaction are important factors affecting staff nurses' turnover intention.

\section{Conclusion}

Professional identity was higher among staff nurses working in Suez Canal university hospital than those working in Shura general hospital. However, turnover intention was higher among staff nurses working in Shubra general hospital than those working in Suez Canal university hospital. There were statistically significant positive correlations between professional identity and staff nurses' age and years of experience. There were statistically significant negative correlations between turn over intention and staff nurses' age and years of experience in both settings. There was statistically negative correlation between professional identity and turnover intention among staff nurses in different sectorial settings.

\section{Recommendations}

- Develop staff nurses professionally through boosting up the assertive behavior

- Nurse Managers should develop strategies to knob turnover intention.

- Nurse Managers have to offer support for staff nurses to express their feelings and problems related to work issues.

- Nurse leaders need to create strategies for developing nursing staff by maintaining safe work environment, providing valued rewards, offering opportunities for growth, valuing professional development and encouraging innovation and creativity in the work environment.

- Nurse leaders have to allow staff nurses to share in decision making and put their suggestions into considerations.

- Highly performer and assertive staff nurses should be praised and act as a role model for their colleagues especially newly and younger ones.

- Professional identity as a concept should be addressed in nursing education curricula and reflected by graduates behavior and actions.

\section{Further researches are suggested:}

- Assess factors affecting staff nurses' professional identity.

- Assess factors contributing to nurses' turnover intention. 
- Explore the relationship between professional identity and empowerment.

- Investigate leadership style of nurse managers and its influence on staff nurses' turnover intention.

\section{Implications of the study:}

This study finding will provide nurse managers with importance of ongoing education and benefits of creating highly challenged work environment for their staff to enhance their professional identity. Positive sharing in different hospital committees and teams and also be oriented with the syndicate contributions and activities in the community and had active participation in it. Nurse Managers must develop strategies that support nurses' professional identity and establish appropriate policies to eliminate turnover intention as periodic rotation of nurses, apply pull out policy, and improve work conditions, fair reward and deserved promotions.

\section{References}

[1]. Abd ElAziz,M. and Mohamed , R.( 2009): Clinical Teaching Behaviors and Students self confidence ,New Egyptian journal of Medicine , 17(5): 409-416.

[2]. Adams, R. (2011): Exploring dual professional identities, the role of the nurse tutor in higher education in UK: Role complexity and tensions, journal of Advanced nursing, 67: 884-892.

[3]. Adriaenssens, J., De Gucht, V., and Maes, S.(2015): Causes and consequences of occupational stress in emergency nurses, a longitudinal study, journal of Nursing Management, 23( 3); 346-358.

[4]. Almalki, M., Fitzgerald,G. and Clark,M.( 2012 ): The relationship between quality of work life and turnover intention of primary health care primary nurses in Saudi Arabia , BMC Health services Research,12(1); 314-325.

[5]. Benner, P., Sutphen, M., Leonard, V. and Day, L. (2010) :Educating nurses:

[6]. Call forradical transformation. San Francisco: Jossey-Bass

[7]. Bukhan, J. and Aikan, L. (2008): Solving nursing shortages: a common priority. Journal of Clinical Nursing, 17(24), 3262-3268.

[8]. Bucher ,R. and Strauss, A.(2011): Professions in process, American journal of Sociology,66(4): 325-334.

[9]. Celik ,S. \&Hisar F. (2012): The influence of the professionalism behavior of nurses working in health institutions on job satisfaction. International Journal of Nursing Practice 18 (2): 180-187

[10]. Cole, B.(2014): The relationship between job demands ,job resources, engagement, burnout and intention to quit ,Master thesis , Human resource management, Stellenbosch University, pp.30-31,76-78.

[11]. Cortese, C.(2012): Predictors of critical care nurses' intention to leave the unit ,the hospital and the profession, Open journal of nursing, 2(3): 311-326.

[12]. Cowin L.S., Johnson M., Wilson I. \&Borgese K. (2013): The Psychometric

[13]. properties of five professional identity measure in a sample of nursing students, Nursing Education Today,33: 608-613.

[14]. Cowin L.S., Maree J., Rhonda G.C. \& Herbert W.M. (2008): Causal modeling of self-concept, job satisfaction, and retention of nurses. International Journal of Nursing Studies, 45(10), 14-49.

[15]. Dasgupta, P. and Agarwal, U. (2014): Intention of nurse to leave or live in same hospital: a qualitative study in private hospitals. Globysn Management Conference, New Delhi: Allied Publishers; 170:182.

[16]. Deppoliti, D. (2008) :Exploration how new registered nurses construct professional identity in hospital settings ,journal of Continuing Education in Nursing, 39(6): 255-262

[17]. Drennan,V., Halter,M., Grant, R., Gale, J., Harris ,R. and Gourlay,S.(2015): Adult nurse turn over and retention: South London Project report ,Faculty of Health ,Social care and education, Kingston University and St George university of London, pp. 22-23, 33.

[18]. Dunn, M. and Sommer, N.(2008): Managing difficult Staff interactions : Effectiveness of assertiveness training for nursing staff, Rehabilitation nursing Research, 22(2): 82-88.

[19]. El Dahshan, M. E. and Keshk, L. I. (2014): Managers' Conflict Management Styles and its Effect on Staff Nurses' Turnover Intention at Shebin El Kom Hospitals, Monufiya Governorate. World Journal of Medical Sciences, 11 (1): $132-143$.

[20]. El Sakka,N. (2016): The relationship between person organization fit ,burnout and turnover intention among CIC academic staff, the business and management review,7(2):53-67.

[21]. Fagermoen, M. (2010): Professional identity: values embedded in meaningful nursing practice, journal of Advanced Nursing, 25: 440-449.

[22]. Flinkman,M., Bouret,U.\&Salantera,S.(2013):Young Registered Nurses' Intention to Leave the Profession and Professional Turnover in Early Career: A Qualitative Case Study, International Scholarly Resaech Notices,

[23]. Friberg, E. E. and Creasia, J. L. (2016): Conceptual Foundations: The Bridge to Professional Nursing Practice. $6^{\text {th }}$ ed.,St. Louis: Elsevier; p.p: 40, 41.

[24]. Gault, I.;Shapcott,J.;Luthi, A., and Reid, G.(2017): Communication in Nursing and Healthcare: A Guide for Compassionate Practice. Los Angeles: SAGE; 19:25.

[25]. Getie,G.A., Betre,E.T.,andHareri,A.H.(2015): Assessment of factors affecting Turnover Intention among nurses working at Governmental health care institutions in East Gojjam, Amhare Region ,Ethiopia 2013, American journal of nursing science , 4(3): $107-112$

[26]. Giddens, J. F. (2017): Concepts for Nursing Practice. $2^{\text {nd }}$ ed.,St. Louis: Elsevier; p.p: 379-385,441.

[27]. Harrison,T. R. and Williams, E. A. (2016): Organizations, Communication, and Health. Abingdon: Rout ledge; p: 153:159.

[28]. Herholdt, K. (2015): Determinants of work engagement and organizational citizenship behavior among nurses, Master thesis, Faculty of Economics and Management Science, Stellenbosch University.

[29]. Hoeve Y ., Jansen, G. and Roodbol, P. (2014): The nursing profession: public image, self-concept and professional identity. A discussion paper. Journal of Advanced Nursing 70(2), 295-309.

[30]. Hwang I.J., Lou S.S., Han F., Cao W., Kim O. \& Li P. (2009) :Professionalism: the major factor influencing job satisfaction among Korean and Chinese nurses. International Nursing Review 56, 313-318.

[31]. Iacobucci, T., Daly, B., Lindell, D., \& Griffin, M. (2013): Professional values,Self esteem and ethical confidence of baccalaureate nursing students, Nursing Ethics,20(40: 479-490

[32]. Johnson, M., Cowin, L., Wilson, I. and Young, H. (2012): Professional identity andnursing: Contemporary theoretical developments and future research challenges. International Nursing Review, 59(4):562-569. 
[33]. Jourdain, G., and Chenevert, D. (2010): Job demands-resources, burn out, and intention to leave to leave the nursing profession : A questionnaire survey, International Journal of Nursing Studies, 47(6): 709-722.

[34]. Juraschek, S.P., Zhang, X.; Ranganathan, V. K.and Lin, V.W. (2012): United States Registered Nurse Workforce Report Card and Shortage Forecast. American Journal of Medical Quality, 27(3): 241-249.

[35]. Kabeel, A.M. (2004): Developing a tool for assessing nurses' professional identity at Cairo University Hospitals, Unpublished Master Thesis, Faculty of nursing, Cairo University.

[36]. McGiltona,K.,Boscart,V.,Brown,M.,andBowers,B.(2014): Making tradeoffs between the reasons to leave and reasons to stay employed in long term care homes: perspectives of licensed nursing staff, International journal of nursing studies, 51(6): 917-926.

[37]. McNiesh, S., Benner, P. and Chelsea, C. (2011): Learning formative skills of Nursing practice in an accelerated program, Qualitative Health Research, 21(1):51-61

[38]. Miskelly, P. and Duncan, L. (2014):'I'm actually being the grown-up now': Leadership, maturity and professional identity development. Journal of Nursing Management, 22(1), 38-48.

[39]. Mohamed, N., and Mohamed, S., (2013): Impact of job demand and control on nurses intention to leave obstetrics and gynecology department, Journal of Life Science, 10(2):223-229.

[40]. Momanyi, N., and Kaimenyi, C. (2015): An investigation into factors causing high nurse turnover in Mission hospitals in Kenya: a case for Pceachogoria hospital, International journal of Academic Research in Business and Social Science, 5(4): 64-77.

[41]. Moreland, J. J., Ewoldsen, D. R., Albert, N. M., Kosicki, G. M. and Clayton, M. F. (2015): Predicting Nurses' Turnover: The Adversive Effects of Decreased Identity, Poor Interpersonal Communication, and Learned Helplessness. Journal of Health Communication, 20(10): 1155-1165.

[42]. Mosadeghrad, A. M. (2013): Occupational Stress and turnover intention: Implications for nursing management, International journal of Health policy and management, (2): 169-176.

[43]. Mosallam, R.; Hamidi, S. and Elrefaay, M.(2015):Turnover intention among intensive care unit nurses in Alexandria, Egypt. Journal of the Egyptian Public Health Association, 90(2):46-51.

[44]. Nawaz, M., Pangil, F. and Bhatti, M.(2015): The relationship between human resource development factors and turnover intention : A conceptual framework, International journal of Academic Research in Business and Social Science,5(12): 297-306

[45]. Omar, H., Anuar, M., Ismail, R. and Din , B.(2015): Nurses' intention to leave : Do demographic factors matter? Journal of human resource management and labor studies, 3(2): 53-63.

[46]. Rainayee,R.(2013): Employee turnover intentions: job stress or perceived external opportunities, International journal of information, Business and management ,51(1): 48-54.

[47]. Roussel,L.; Thomas, P. and Harris, J. (2016): Management and Leadership for Nurse Administrators. $7^{\text {th }}$ ed., Burlington: Jones \& Bartlett learning; p.p: 219: 220.

[48]. Sabanciogullari, S. and Dogan, S. (2015): Relationship between job satisfaction, professional identity and intention to leave the profession among nurses in Turkey, Journal of Nursing Management.23(8):1076-85.

[49]. Salminen, H. (2012):Turning the tide: Registered nurses' job withdrawal intentions in a Finnish university hospital, SA Journal of Human Resource Management, 10 (2): 1-11.

[50]. Seid, A.(2015): Assessment of the magnitude and associated factors of turnover intention among nurses in TikurAnbessa specialized hospital, Addis Ababa, Master thesis, School of health science ,Department of nursing and midwifery, Addis Ababa university ,pp.27-31.

[51]. Sermeus, W. and Bruyneel, L. (2010): Investing in Europe's health workforce of tomorrow: scope for innovation and collaboration. Summary Report of the Three Policy Dialogues. Available from http://www.healthworkforce4europe.eu/downloads/Re- port PD Leuven FINAL.pdf.

[52]. Severinson, E. and Sand, A. (2010) : Evaluation of the clinical supervision and professional development of student nurses. Journal of Nursing Management, 18(6): 669-677.

[53]. Shacklock,K., Brunetto,Y.,Teo,S.,and Farr-Wharton ,R.(2014): The role of support antecedents in nurses' intentions to quit : The case of Australia, Journal of Advanced Nursing,70(4): 811-822.

[54]. Sharbaugh, S.M. (2009): Relationships among Nurses' Professionalldentity, Career Satisfaction, Occupational Commitment,and Intent to Stay. Doctoral dissertation, Faculty of the School of Nursing Widener University,

[55]. Steinmetz,S., De Vries,D., and Tijdens,K.(2014): Should I stay or should I do? The impact of working time and wages on retention in the health workforce, Human Resource for health , 12(23): 3-14

[56]. Takase, M. (2010): A concept analysis of turnover intention: implications for nursing management. Collegian, 17(1):3-12.

[57]. Thirapatsakun, T., Kuntonutr, C., and Mechinda, P.(2015): The relationships among four factors and turnover intentions at different levels of perceived organizational support, journal of US-China public Administration ,12(2): 89-104.

[58]. World Health Organization (WHO) (2011): World Health Statistics, http://www.who.int/whosis/whostat/2011/en/index.html.

[59]. Yeun,E., and Jeon,M.(2015): Relationship between nursing professionalism ,internal marketing ,and turnover intention among hospital nurses, Indian journal of Science and technology ,8(25) : 1-6

[60]. Yeun,E.,andKim,H.(2015): The effect of supervisor support, emotional exhaustion and sense of personal accomplishment on hospital nurse turnover intentions, Indian journal of Science and technology , 8(25): 63-68.

Rabab M. Hassan. "Sectorial Hospitals ." IOSR Journal of Nursing and Health Science (IOSR-JNHS) 6.4 (2017): 29-37 